\title{
Antiresorptive Effects of Simvastatin and OPG on Polyethylene Particle-Induced Osteolysis
}

\section{Die antiresorptive Wirkung von Sim- vastatin und OPG auf die Polyethy- lenpartikel-Induzierte Osteoylse}

\begin{abstract}
Die Entwicklung neuartiger pharmakologischer Interventionsmöglichkeiten basiert auf dem größer werdenden Verständnis der aseptischen Prothesenlockerung. In dieser Untersuchung wurde der Effekt von Simvastatin und Osteoprotegerin (OPG) auf die UltraHigh-Molecular-Weighted-Polyethylene (UHMWPE)-Partikel-induzierte Osteolyse untersucht. Die Daten zweier vorangegangener Studien am murinen Kalvariamodell für UHMWPE-Partikel-induzierte Osteolysen wurden gepoolt. Die Versuchstiere wurden in vier Gruppen gegliedert, Tiere in Gruppe I erhielten eine Kontrolloperation, während den Tieren der anderen Gruppen zusätzlich UHMW$P E$-Partikel auf die Kalvaria implantiert wurden. Postoperativ erhielten die Tiere in Gruppe III Simvastatin und die Tiere der Gruppe IV OPG. Die UHMWPE-Partikel induzierten eine ausgeprägte osteolytische Aktivität im Sinne einer erhöhten Knochenresorption $(p<0,001)$ sowie einer Zunahme der Osteoklastenzahl $(p<0,001)$, die sowohl durch Simvastatin als auch OPG gehemmt werden konnte. In der Gegenüberstellung der Ergebnisse beider Behandlungsformen zeigten sich signifikante Unterschiede der beiden Substanzen, bei einer ausgeprägteren Knochenresorption in den mit Simvastatin behandelten Gruppen gegenüber den mit OPG behandelten Gruppen $(p=0,05)$, jedoch mit signifkant mehr Osteoklasten in der OPG Gruppe $(p=0,002)$. Somit scheint OPG in der Inhibition der partikelinduzierten 0steolyse von höherer Potenz zu sein. Dennoch haben beide Substanzen eine nachgewiesene, ausgeprägte inhibitorische Wirkung auf die partikelinduzierte Osteolyse und könnten somit zukünftig in der Prävention der Prothesenlockerung von Bedeutung sein.
\end{abstract}

\begin{abstract}
Autoren: Christian Wedemeyer ${ }^{1}$, Carl Neuerburg $^{1}$, Anja Heckelei ${ }^{1}$, Fabian von $\mathrm{Knoch}^{2}$, Jie $\mathrm{Xu}^{3}$, Guido Saxler ${ }^{1}$ Franz Löer ${ }^{1}$, Marius von Knoch $^{1}$
\end{abstract}

Schlagworte: Endorothetik - Statine - 0steoprotegerin - Osteolyse - Polyethylen Partikel

Keywords: Arthroplasty - Statins - 0steoprotegerin - 0steolysis Polyethylene particles

Zitierweise dieses Beitrages: BIOmaterialien 2007; 8 (4): S.305-310

\section{Introduction}

Aseptic loosening due to periprosthetic osteolysis is known to be the main and most frequent long-term complication after hip replacement surgery [14]. Implant wear particles have been observed to be the major cause of aseptic loosening. Depending on the prosthetic model, particles of ultra-high molecular

1 Department of Orthopaedics, University of Duisburg-Essen, Pattbergstrasse 1-3, 45239 Essen, Germany

2 Department of Orthopaedic Surgery, Schulthess Clinic, Lengghalde 2, 8008 Zürich, Switzerland

3 Department of Orthopaedics, The second affiliated hospital of Sun Yat-sen University Guangzhou, China weight polyethylene (UHMWPE) followed by polymethylmethacrylate, titanium and osseous particles are the wear debris most frequently found in the surrounding tissue [7]. Macrophages activated by the absorbtion of implant wear particles at the border between bone and the implanted prosthesis initiate an inflammatory response by producing cytokines such as TNF-alpha, IL-1 and IL-6 [13]. A periprosthetic inflammation arising from this process eventually leads to enhanced bone resorption via osteoclasts $[1,24]$. In order to reduce the generation of wear particles and thus prevent complications due to aseptic loosening enormous efforts have been made to develop improved prosthetic materials [11]. 
Noninvasive alternatives for the prophylaxis and treatment of periprosthetic osteolysis would be favourable. This opens up an opportunity for improved pharmacological intervention. Statins and osteoprotegerin (OPG) seem to be adequate agents. Simvastatin is a precursor of an inhibitor of the HMG-CoAReductase, the key enzyme in cholesterol biosynthesis. Statins such as Simvastatin are used to reduce serum cholesterol levels, simultaneously lowering the risk of a myocardial infarction [4]. Mundy et al. proved that statins such as Simvastatin and Lovastatin are also capable of increasing osseous regeneration under in vivo and in vitro circumstances [10]. The mechanism by which statins stimulate osseous regeneration consists of an increased expression of the Bone-Morphogenetic-Protein 2(BMP-2). BMP-2 plays an important role in fracture healing and osseous regeneration [25]. In addition, this leads to an increased production of alkaline phosphatase's (ALP). Simvastatin inhibits collagenase 1, causing an accumulation of collagen 1 , eventually resulting in increased mineralisation of regenerated bone [9]. Another trial [8] revealed that Simvastatin increases the phosphorylation of the endothelially located nitrate-monoxide-synthesis. Within the endothelial cells this process leads to an increased production of nitrate-monoxide (NO) which again enhances angiogenesis. Hence, increased osseous regeneration by means of Simvastatin is likely to be encouraged via angiogenesis [9]. The ability of statins to suppress osteoclast-induced bone resorption has also been reported under in vitro $[17,29]$ and in vivo circumstances [10]. The second agent to be evaluated in this trial is osteprotegerin (OPG). OPG directly affects osteoclasts and thereby controls their activity, such as osteoclastogenesis and the interaction between osteoclasts and osteoblasts. This is linked to the cooperation between the three members of the TNF-family: RANKL (receptor-activator of NFKB-Ligand), RANK (receptor-activator of NFKB) and OPG. OPG is a protein that consists of $401 \mathrm{ami}-$ no acids occurring as a Type II-Transmembrane-Protein [28] and a dissolved mode [3]. Simonet et al. [15] and Yasuda et al. [26] detected OPG mRNA in numerous tissues such as lungs, heart, kidneys, liver, gastrointestinal tract, central nervous system, thyroid and bone. As mentioned before, osteoclastogenesis is controlled via interaction of OPG, RANKL and RANK. RANKL, expressed on the surface of osteoblast precursors, binds RANK which is also expressed on the surface of osteoclast precursors [19]. RANKL is essential for the differentiation of osteoclasts, the fusion of multinuclear cells, their activation and the survival of osteoclasts. OPG, however, represses this mechanism by inhibiting the RANKL induced cascade, as it binds the osteoblast precursors itself.

This study primarily aimed to evaluate the anti-resorbing effects of Simvastatin and OPG, comparing the agents under equal conditions within a reproductive animal model, the murine calvarial model for UHMWPE-particle induced osteolysis $[20,21]$.

\section{Materials and Methods}

\section{Animal model}

Within the present study the data sets of two recently completed trials [20,21] were pooled and applied for a comparative analysis. In these two trials, the murine calvarial model for UHMWPE-particle-induced-osteolysis was used in a total of 28 healthy 14-week old male C57BL/J6 mice, in compliance with the university's ethics committee and the official guidelines. The experiments were all performed under the same conditions.

28 animals were divided randomly into four experimental groups. In Group I a control operation was performed. The animals in Groups II, III and IV received an additional UHMWPEparticle implantation (approx. 6 × $10^{6}$ particles in each animal) on the calvaria as illustrated in Table 1. Furthermore, the animals in Group III received Simvastatin (Zocor, Merck, Rahway, NJ, U.S.A.). Simvastatin was applied via special food (Altromin 1324, Altromin, Lage, Germany), ensuring a daily Simvastatin dose of approx. $120 \mathrm{mg} / \mathrm{kg}$ per mouse, starting on the day of the surgical procedure and lasting till sacrifice. The average daily dose of Simvastatin was assessed by controlling the food given individually on day $0,5,10$ and 14 postoperatively. The chosen dosage and method of application is based on a trial dealing with fracture healing published previously by Skoglund et al. $[16,20]$. The animals in Groups IV received a daily dose of $3 \mathrm{mg} / \mathrm{kg}$ Fc-OPG intra peritoneal according to their weight[21]. Fc-OPG was kindly provided by Amgen (Amgen, Thousand Oaks, California, USA).

\section{Particles}

The company Clariant (Gersthofen, Germany) supplied the commercially pure UHMWPE polyethylene particles (Ceridust VP 3610). More than 34\% of the particles were smaller than 1 $\mu \mathrm{m}$ with a mean particle size (given as Equivalent Circle Diameter) of $1.74 \pm 1.43 \mu \mathrm{m}$ (range 0.05 to $11.06 \mu \mathrm{m}$ ) [22]. For decontamination of endotoxins the particles were washed twice in 70\% ethanol for 24 hours. Testing for endotoxins using a quantitative Limulus Amebocyte Lysate (LAL) Assay (Charles River, Kent, United Kingdom) at the detection level of $<0.25$ $\mathrm{EU} / \mathrm{ml}$ was negative.

\section{Surgical procedure}

The surgical procedure has already been described [23]. Before surgery, the mice were anaesthetized with $70-80 \mathrm{mg} / \mathrm{kg}$ ketamine (CEVA, Sante animale Ketaminhydrochlorid, Düsseldorf, Germany) and 5-7 mg/kg xylazine (CEVA, Sante animale Xylazinhydrochlorid, Düsseldorf, Germany) by intraperitoneal injection. A $10 \mathrm{~mm}$ incision was made over the calvarian sagittal midline suture. A $1.0 \times 1.0 \mathrm{~cm}$ area of periosteum was exposed and left intact. In the sham controls (Group 1) the incision was closed without any further intervention. Groups II, III and IV received $30 \mu \mathrm{l}$ of dried polyethylene particles $\left(2 \times 10^{8}\right.$ particles per $1000 \kappa l$ (the dosage was established through previous experiments [20,23]) which were distributed over the periost using a sterile sharp surgical spoon. The incision was sutured using 4-0 Ethilon (Ethicon, Somerville, NJ, USA). Water and food were given ad libidum.

\section{Specimen retrieval and histological processing}

The calvaria were removed as an elliptical plate of bone. Specimens were dehydrated by acetone (one day in 95\% and six days in 100\%) before infiltration with polymethylmethacrylate. The embedded tissues were cut into four- $\mu \mathrm{m}$ sections in the coronal plane using a Reichert-Jung microtome (Model 2065, Heidelberg, Germany). These sections were stained with Goldner dye and TRAP (tartrate resistant acid phosphatase).

\section{Bone histomorphometry}

Using a standard high-quality light microscope the specimens were photographed with a digital camera (Coolpix 995, Nikon, Düsseldorf, Germany). Each section was digitally photographed at a magnification of $10 x$ with the midline suture in the middle of the field. A histomorphometric analysis was made by a system consisting of a personal computer and image analysis software (UTHSCA Image Tool, IT Version 3.0, University of Texas, San Antonio, TX, USA). The area of soft tissue including any bone resorption pits in the midline suture was traced in 
Goldner sections as described previously $[12,20]$ to determine the bone resorption area in the midline suture. In detail, using one microscopic field at a magnification of $10 x$, the regions of interest, i.e. the non-osseous tissue area adjacent to and in continuity with the midline suture, were encircled by the operator; the software recorded and calculated the determined area automatically.

Within this field the number of osteoclasts was determined. Osteoclasts were identified as large multi-nucleated TRAP-positive cells located on the bone perimeter within a resorption lacunae. The values of each available section were averaged per animal. These averages per animal for the bone resorption area as well as for the number of osteoclasts were averaged again for each group.

\section{Statistical analysis}

The results were expressed as means and standard errors of the mean. The data were analyzed by one-way ANOVA, followed by the post-hoc paired Student's two-tailed t-test. Pearson's correlation coefficient was performed to evaluate the linear relationship between the bone resorption and osteoclasts in all groups. All p-values were compared to an $\alpha$-value of 0.05 to determine significance.

\section{Results}

Except for one animal in Group I which did not recover from anaesthesia, all animals underwent a flawless peri- and postoperative course. Fourteen days postoperatively, the animals were sacrified. Within the surgically treated area, fibrous and granulated scar tissue was found. An implant of UHMWPEparticles without any further treatment (Group II) resulted in a distinctively increased bone resorbing activity compared to the control group. Additional daily treatment with Simvastatin (Group III) or OPG (Group IV) inhibited the particle-induced effect significantly; at this stage OPG had an improved anti-resorbing effect (Fig. 1 A-D). The pooled bone histomorphometric data revealed the following values for Groups I to IV.
Bone resorption within the range of the midline suture was $0.108 \mathrm{~mm}^{2} \pm 0.009 \mathrm{~mm}^{2}$ in animals without particle implantation (Group I), $0.257 \mathrm{~mm}^{2} \pm 0.019 \mathrm{~mm}^{2}$ in animals with particle implantation without any further intervention (Group II), $0.131 \mathrm{~mm} 2 \pm 0.02 \mathrm{~mm}^{2}$ following particle implantation and additional daily treatment with Simvastatin (Group III), $0.09 \mathrm{~mm}^{2}$ $\pm 0.01 \mathrm{~mm}^{2}$ following particle implantation and additional daily treatment with OPG (Group IV), as illustrated in Figure 2. Statistically significant differences in bone resorption were found in the comparisons of Groups I and II ( $p<0.001)$, Groups II and III ( $p=0.0037)$ and Groups II and IV ( $p=0.03)$. A comparison between the animals treated with a daily dose of Simvastatin (Group III) and those treated with a daily dose of OPG (Group IV) revealed a statistically significant difference $(\mathrm{p}=0.05)$.

The osteoclast number was $11.8 \pm 2$ in Group I, $34.4 \pm 5.3$ in Group II, $6.2 \pm 3.1$ in Group III, and $21.1 \pm 5.6$ in Group IV as illustrated in Fig. 3. Comparison between Groups I and II $(\mathrm{p}<0.001)$, Groups II and III $(\mathrm{p}<0.001)$, Groups II and IV revealed significant differences $(\mathrm{p}<0.001)$. Again, there were also statistically significant differences $(p=0.002)$ between the animals treated with a daily dose of Simvastatin (Group III) and those treated with a daily dose of OPG (Group IV).

A positive correlation was found between the bone resorption and the number of osteoclasts using linear regression analysis in Group I and Group II as illustrated in Figure $4(p=0.0006)$. This means that increased bone resorption induced by particles was accompanied by an increase in osteoclasts. However, the correlation between bone resorption and the number of osteoclasts was not significant in either Group III or Group IV which were treated with Simvastatin and OPG respectively.

\section{Discussion}

Comparison of the effects induced via Simvastatin [21] and OPG [22] respectively in the calvaria model of UHMWPE-particle induced osteolysis was intended to evaluate the difference between the two substances under equal conditions. In the

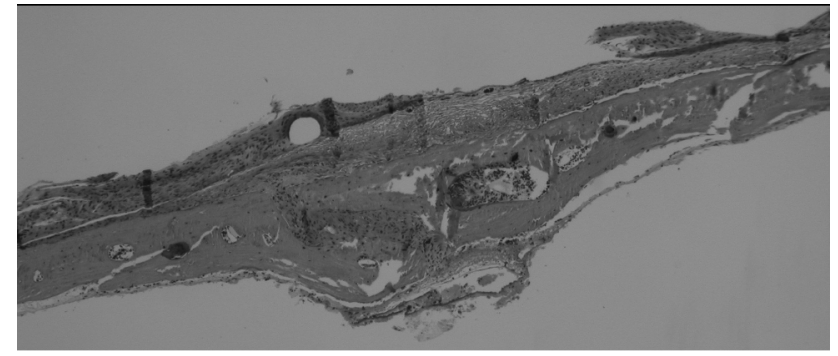

A

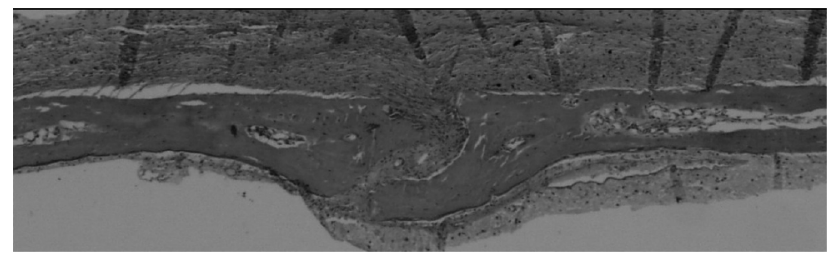

]B

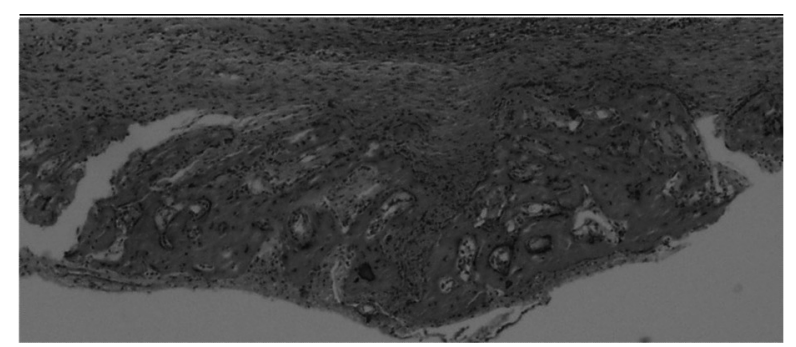

C

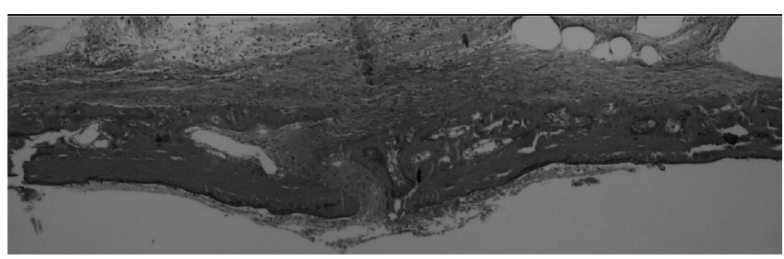

D

Fig. I a-d: Representative micro-photography of the calvaria-histology: (A) Control group (Group I); (B) Post-UHMWPE-particle implantation only (Group II), (C) Post-UHMWPE-particle implantation and additional treatment with Simvastatin (Group III), (D) Post-UHMWPE-particle implantation and additional treatment with OPG (Group IV). In all cases, the periosteal surface is at the top of the image and the eroded surface is located centrally. 
groups that underwent particle implantation, a significant increase in the proinflammatory reaction was detectable in comparison with their corresponding control group. Simultaneously, this effect was accompanied by an increased osteoclast proliferation and associated bone resorbing activity. A far more effective treatment was observed within OPG-treated animals in terms of a distinctly smaller eroded surface area compared to the animals treated with Simvastatin. A larger quantity of osteoclasts was seen in Group IV than in animals treated with Simvastatin (Group III). This seemed to be inconsistant, as a large number of studies [18] have found a positive correlation between the number of osteoclasts and bone resorption. This relationship was also shown in our study by Group II with particle implantation.

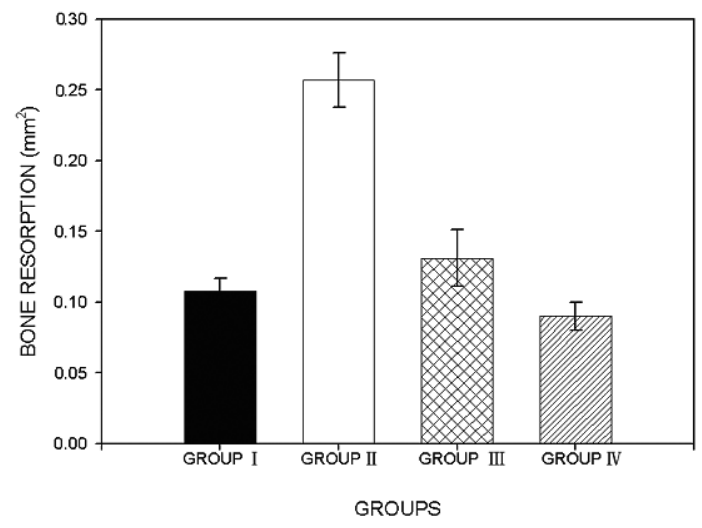

Fig. 2: Bone resorption was estimated as explained in "Materials and Methods" and is expressed as a mean and standard error of the mean for each group individually: After control surgery without UHMWPE-particle implantation (Group I), with particle implantation leaving out further interventions (Group II), animals following particle implantation and additional treatment with Simvastatin (Group III), animals with a daily dose of OPG (Group IV). ( ${ }^{*} p<0.05$ in comparison to Group I; ${ }^{* *} p<0.05$ in comparison to Group II. ${ }^{* \star \star} p<0.05$ in comparison to Group III).

OPG acts as a decoy receptor for RANKL to block the RANKLRANK interaction. The findings in our study correspond to those of many other authors who have shown that OPG inhibits bone resorption. In comparison, the number of osteoclasts in the group treated with OPG was lower than in the control group. Yuko et al. [27] found that OPG reduced the serum level of the receptor activator of NF-kB ligand derived from osteoblasts. This could explain the decrease in the number of osteoclasts because the RANKL activity regulates the differentiation from a macrophage to an osteoclast. The importance of NF-kB in regulating osteoclast differentiation was demonstrated in some studies [6] using mice with knockout of the NF-kB gene. These animals showed an impaired macrophage function and failed to generate mature osteoclasts, resulting in severe osteopetrosis. Even so, it could not explain the lack of correlation between bone resorption and the number of osteoclasts, different from that of control group. It can be assumed from the reduced eroded surface area in mice treated with OPG that osteoclasts in Group IV are clearly inhibited in their activity. One has to be aware that the count of TRAP positive cells reflects the current state only, which does not necessarily reveal osteoclast activity. The same probable mechanism could not be eliminated for Simvastatin.

OPG application (Group IV) seems to be more effective in re-

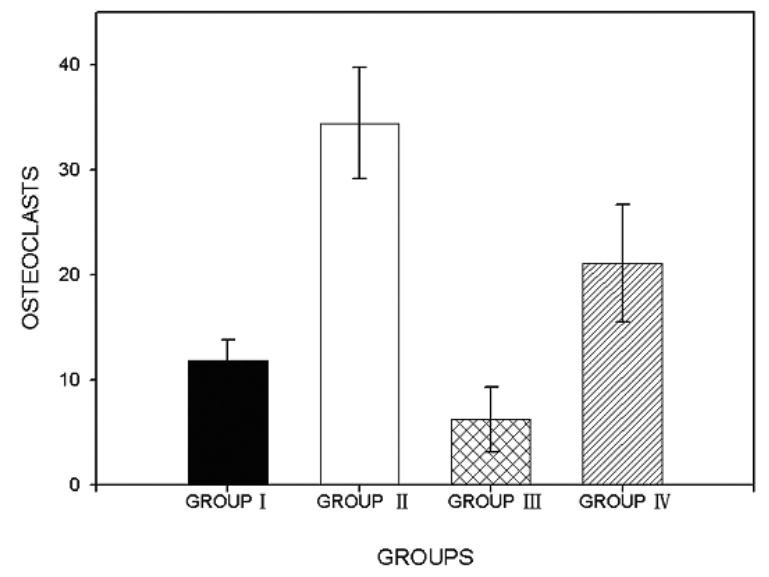

Fig. 3: The number of osteoclasts was estimated as explained in "Material and Methods" and the data are expressed as mean \pm standard error for each group: After surgery without UHMWPE particle implantation (Group I), following UHMWPE particle implantation without any further intervention (Group II) ( $p<0.05$ ), animals following particle implantation and additional treatment with Simvastatin (Group III), animals with a daily dose of OPG (Group IV). $\left({ }^{*} p<0.05\right.$ in comparison to Group I; ${ }^{* *} p<0.05$ in comparison to Group II; *** $p<0.05$ in comparison to Group III).

ducing the bone resorption area by inhibiting osteoclast activity than Simvastatin (Group III). The second stage of the study concerning inhibition of osteoclast activity caused by OPG and Simvastatin respectively is in progress.

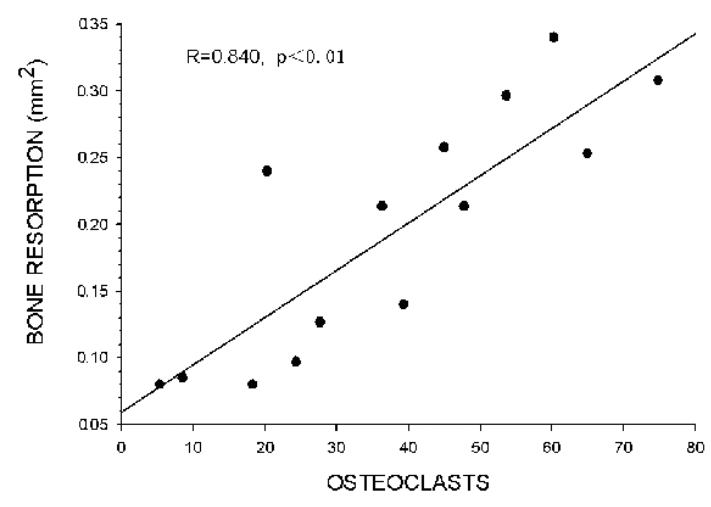

Fig. 4: Close positive correlation has been shown between bone resorption and the number of osteoclasts in Group I and Group II.

The murine calvaria model for particle-induced osteolysis is known to have some limitations. Due to the anatomical conditions in mice, the skull was used instead of the femur as it offers a larger surface. However, the osseous structure is different, the femur consisting mainly of lamellar bone whereas the skull consists of desmoid bone. Furthermore a multiple quantity of the number of polyethylene particles which have been found to occur annually in vivo was implanted onto the mice's skulls. The experiment lasted for only two weeks, but even this short period revealed significant degrees of osteolysis. The results have to be interpreted with caution, as the clinical finding of osteolytic activity is usually initially detectable only after a longer period of time of up to one year. Although there are difficulties and fundamental differences, we are convinced that 
this model enables a rapid and confident analysis of pharmacological agents. The model ensures a highly sensitive, quick, beneficial and effective method of testing potential agents that are able to inhibit particle-induced osteolysis.

\begin{tabular}{|c|c|c|c|c|}
\hline & Group I & Group II & Group III & Group IV \\
\hline UHMWPE & - & + & + & + \\
\hline Simvastatin & - & - & + & - \\
\hline OPG & - & - & - & + \\
\hline
\end{tabular}

Table I

In conclusion, a daily dose of OPG inhibited the process of particle-induced osteolysis due to UHMWPE-particles significantly more effectively than the reference agent simvastatin. However, both agents have proved to be an efficient non-invasive means of preventing and treating particle-induced osteolysis. The clinical relevance of Simvastatin and OPG remains to be determined. It has to be pointed out, that our trial did not attempt to confirm that the problem of an already loosened implant could be solved by the application of Simvastatin or OPG respectively. These agents can only influence the progress of particle-induced osteolysis prior to the time of loosening.

\section{Acknowlegdements}

The study was supported by German Research Foundation (DFG), Bonn, Germany (DFG - KN553/1; DFG - KN 553/2). OPG was kindly provided by Amgen. The authors would like to thank Sylvia Marks for technical assistance and Prof. Dr. Hartmut Stöß for advice during histological and immunhistochemical processing of the specimens and Kaye Schreyer for editorial assistance.

\footnotetext{
Abstract

The development of new pharmacological treatments for aseptic loosening is mainly based on its improved comprehension and molecular decryption. In this study we evaluated the effect of two substances, simvastatin and osteoprotegerin (OPG), in Ultra-High-Molecular-Weight-Polyethylene (UHMWPE)-particle-induced osteolysis.

Data of two previous studies by our group based on the murine calvarial model of particle-induced osteolysis were pooled to form the study groups. The animals were divided into four groups: The animals in Group I received SHAM surgery only, UHMWPE-particles were implanted on the skulls of the animals in the other groups. Apart from the animals in Group II, all the other animals additionally received the substances mentioned above: The animals in Group III postoperatively received a daily dose of simvastatin and the animals in Group IV received a daily dose of $0 \mathrm{PG}$.

Particle implantation resulted in a grossly pronounced osteolytic activity with significantly increased bone resorption values $(p<0.001)$ and osteoclast numbers $(p<0.001)$. Inhibition of particle-induced osteolysis was observed in the animals treated with simvastatin and OPG. In the group treated with simvastatin more bone resorption was observed $(p=0.05)$ while an increased number of osteoclasts $(p=0.002)$ was observed in the
}

group treated with $\mathrm{OPG}$

OPG seemed to have a more decelerating effect on particleinduced osteolysis than simvastatin. However, the study obtained evidence of the inhibitory effect on particle-induced osteolysis of both substances and they both seem to have a direct influence on osteoclast activity. This may play an important role in the prevention of osteolysis and therapy after total hip replacement in the future.

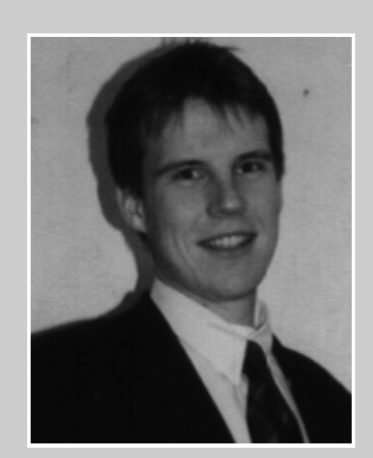

\section{Dr. med. Christian Wedemeyer}

Korrespondenzanschrift:

Klinik für Orthopädie

Universitätsklinikum Essen

Hufelandstr.55

45122 Essen

Tel. +49-201-4089-2140

Fax +49-201-4089-2722

Email: christian.wedemeyer@ uni-duisburg-essen.de

\section{Akademischer Lebenslauf:}

$1998-2004$

Universität Duisburg - Essen:

Studium der Medizin

2003

Forschungsaufenthalt als Research Trainee an der Mayo Clinic, Rochester, MN, USA

2005 Promotion und Promotionspreis der Deutschen Gesellschaft für Biomaterialien e.V. für das Jahr 2005 für die hervorragende Arbeit „Prävention und Behandlung partikelbedingter Osteolysen durch Zoledronat - Eine tierexperimentelle Studie“

2007 Albert-Hoffa-Preis der Norddeutschen Orthopädenvereinigung

Patent Entwicklung eines Knochenersatzstoffes „Struktureller elastischer nicht resorbierbarer Knochenersatzstoff“

\section{References}

[1] Amling M., Neff L, Priemel M., Schilling AF, Rueger JM, Baron R. Progressive increase in bone mass and development of odontomas in aging osteopetrotic c-src-deficient mice. Bone $2000 ; 27$ (5): 603-610.

[2] Bucay N, Sarosi I, Dunstan CR, Morony S, Tarpley J, Capparelli C, Scully S, Tan HL, Xu W, Lacey DL, Boyle WJ, Simonet WS. Osteoprotegerin-deficient mice develop early onset osteoporosis and arterial calcification. Genes Dev 1998; 12. 1260-1268.

[3] Emery JG, McDonnell P, Burke MB, Deen KC, Lyn S, Silverman C, Dul E, Appelbaum ER, Eichmann C, DiPrinzio R, Dodds RA, James IE, Rosenberg M, Lee JC, Young PR. Osteoprotegerin is a receptor for the cytotoxic ligand TRAIL. J Biol Chem 1998; 273. 14262-14367. 
[4] Farnier M., Davignon J. Current and future treatment of hyperlipidemia: the role of statins. Am J Cardiol 1998; 82 (4B): 3-10.

[5] Hofbauer LC, Gori F, Riggs BL, Lacey DL, Dunstan CR, Spelsberg TC, Khosla S. Stimulation of osteoprotegerin ligand and inhibition of osteoprotegerin production by glucocorticoids in human osteoblastic lineage cells: potential paracrine mechanisms of glucocorticoid-induced osteoporosis. Endocrinology 1999; 140: 4382-4389.

[6] Iotsova V, Caamano J, Loy J, Yang Y, Lewin A, Bravo R. Osteopetrosis in mice lacking NF-kappa BI and NF-kappa 82 [see comments]. Nat Med 1997;3:1285-9.

[7] Jacobs JJ, Roebuck KA, Archibeck M, Hallab NJ, Glant TT. Osteolysis: Basic Science. Clin Orthop 2001; 393: 71-77

[8] Kureishi Y, Luo Z, Shiojima I, Bialik A, Fulton D, Lefer DJ, Sessa WC, Walsh K. The HMG-CoA reductase inhibitor simvastatin activates the protein kinase Akt and promotes angiogenesis in normocholesterolemic animals. Nat Med 2000; 6: $1004-1010$.

[9] Maeda T, Matsunuma A, Kawane T, Horiuchi N. Simvastatin promotes osteoblast differentiation and mineralization in MC3T3-E1 cells. Biochem Biophys Res Commun 2001; 280: 874-877.

[10] Mundy G, Garrett R, Harris S, Chan J, Chen D, Rossini G, Boyce B, Zhao M., Gutierrez G. Stimulation of bone formation in vitro and in rodents by statins. Science 1999: 286: 19461949.

[11] Muratoglu OK, Bragdon CR, O'Connor, DO, Jasty M, Harris WH. A novel method of cross-linking ultra-high-molecularweight polyethylene to improve wear, reduce oxidation, and retain mechanical properties. Recipient of the 1999 HAP Paul Award. J Arthroplasty 2001; 16 (2): 149-160.

[12] Parfitt AM. Bone histomorphometry : proposed sytem for standaziation of nomenclature, symbols, and units. Calcif Tissue Int $1988 ; 42(5)$ : 284-86.35

[13] Schwarz EM, Lu AP, Goater JJ, Benz EB, Kollias G, Rosier RN, Puzas JE, O'Keefe RJ. Tumor necrosis factor-alpha/nuclear transcription factor-kappaB signaling in periprosthetic osteolysis. J Orthop Res 2000 b;18(3): 472-80.

[14] Silva MJ, Sandell LJ. What's New in Orthopaedic Research. J Bone Joint Surg 2002; Am 84A (8): 1490-1496.

[15] Simonet WS, Lacey DL, Dunstan CR, Kelley M, Chang MS, Luthy R, Nguyen HQ, Wooden S, Bennett L, Boone T, Shimamoto G, DeRose M, Elliott R, Colombero A, Tan HL, Trail G, Sullivan J, Davy E, Bucay N, Renshaw-Gegg L, Hughes TM, Hill D, Pattison W, Campbell P, Boyle WJ. Osteoprotegerin: a novel secreted protein involved in the regulation of bone density. Cell 1997; 89: 309-319.

[16] Skoglund B, Forslund C, Aspenberg P. Simvastatin improves fracture healing in mice. J Bone Miner Res 2002; 17:2004-2008.

[17] Staal A, Frith JC, French MH, Swartz J, Gungor T, Harrity TW, Tamasi J, Rogers MJ, Feyen JH. The ability of statins to inhibit bone resorption is directly related to their inhibitory effect on HMG-CoA reductase activity. J Bone Miner Res 2003; 18 (1): 88-96.

[18] Teitelbaum SL, Abu-Amer Y, Ross FP. Molecular mechanism of bone resorption. J Cell Biochem 1995; 59: 1-10.

[19] Udagawa N, Takahashi N, Akatsu T, Tanaka H, Sasaki T, Nishihara T, Koga T, Martin TJ, Suda T. Origin of osteoclasts: mature monocytes and macrophages are capable of differentiating into osteoclasts under a suitable microenvironment prepared by bone marrow-derived stromal cells. Proc Natl Acad Sci USA 1990; 87: 7260

[20] von Knoch, F., Heckelei, A., Wedemeyer, C., Saxler, G., Hilken, G., Henschke, F., Löer, F., von Knoch, M. The effect of simvastatin on polyethylene particle-induced osteolysis. Biomaterials 2005; 26:3549-3555.

[21] von Knoch F, Heckelei A, Wedemeyer C, Saxler G, Hilken G, Henschke F, Löer F, von Knoch M. Suppression of Polyethylene Particle-Induced Osteolysis by Exogenous Osteoprotegerin. Journal of Biomedical Materials Research 2005; A 75 (2): 288-294.

[22] von Knoch M, Sprecher C, Barden B, Saxler G, Löer F, Wimmer M. Grösse und Form kommerziell erhältlicher Polyethylenpartikel für in vitro und in vivo Versuche. Z Orthop 2004; 142:366-370.

[23] von Knoch M, Wedemeyer C, Pingsmann A, Von Knoch F, Hilken G, Sprecher C, Henschke F, Barden B, Löer F. A Single Dose of Zoledronic Acid Markedly Decreases Particle-Induced Bone Resorption. Biomaterials 2005; 26: 1803-08.

[24] Willert HG, Bertram H, Buchhorn GH. Osteolysis in alloarthroplasty of the hip. The role of ultra-high molecular weight polyethylene wear particles. Clin. Orthop. 1990; 258:95-107. [25] Wozney JM. Bone morphogenetic proteins. Prog Growth Factor Res 1989; 1: 267-280.

[26] Yasuda H, Shima, N, Nakagawa N, Mochizucki SI, Yano K, Fujise N, Sato Y, Goto M, Yamaguchi K, Kuriyama M, Kanno T., Murakami A, Tsuda E, Morinaga T, Higashio K. Identity of osteoclastogenesis inhibitory factor (OCIF) and osteoprotegerin (OPG): a mechanism by which OPG/ OCIF inhibits osteoclastogenesis in vitro. Endocrinology 1998; 39: 1329-1337.

[27] Yuko Nakamichi, Nobuyuki Udagawa, Yasuhiro Kobayashi et al. Osteoprotegerin reduces the serum level of receptor activator of NF-kB ligand derived from osteoblasts. Immunology, 2007,178: 192-200.

[28] Yun, TJ, Chaudhary PM, Shu GL, Frazer JK, Ewings MK, Schwartz SM, Pascual V, Hood LE, Clarc EA. OPG/ FDCR-1, a TNF-receptor family member, is expressed in lymphoid cells and is up-regulated by ligating CD40. J Immunol 1998; 161: 6113-6121.

[29] Zhang FL, Casey PJ. Protein prenylation: Molecular mechanisms and functional consequences. Annu Rev Biochem 1996; 65: 241-269. 